\title{
Correction: Determinants of the creatinine clearance to glomerular filtration rate ratio in patients with chronic kidney disease: a cross- sectional study
}

Yen-chung Lin ${ }^{1,2,3^{*}}$, Nisha Bansal ${ }^{3}$, Eric Vittinghoff ${ }^{4}$, Alan S Go ${ }^{4,5}$ and Chi-yuan Hsu ${ }^{3}$

\begin{abstract}
After the publication of our paper Lin et al. "Determinants of the creatinine clearance to glomerular filtration rate ratio in patients with chronic kidney disease: a cross-sectional study" BMC Nephrology 2013, 14:268, we became aware of errors in the manuscript arising from to a misunderstanding of serum creatinine calibration in the released Chronic Renal Insufficiency Cohort (CRIC) study data obtained from the National Institute of Diabetes and Digestive and Kidney Diseases (NIDDK) Data Repository. Specifically further multiplication by 0.95 was actually not necessary to arrive at the standardized creatinine values.

Here we present the revised results of the re-analyses along with revisions of the relevant tables. Mean $\mathrm{CrCl} / \mathrm{iGFR}$ ratio should be $1.13 \pm 0.46$ instead of $1.19 \pm 0.48$. The main conclusion of the paper remain unchanged: "Contrary to what had been suggested by prior smaller studies, CrCl/GFR ratio does not vary with degree of proteinuria or race/ethnicity. The ratio is also closer to 1.0 than reported by several frequently cited reports in the literature."
\end{abstract}

\section{Discussion}

Under Abstract Results: it should read "Mean $\mathrm{CrCl} / \mathrm{iGFR}$ ratio was $1.13 \pm 0.46$. There was no association between the $\mathrm{CrCl} / \mathrm{iGFR}$ ratio and urine albumin (coefficient 0.10 [95\% CI $-0.01-0.21]$ for higest verus lowest levels of albuminuria, $p=0.07$ ). Also, there was no association between race/ethnicity and $\mathrm{CrCl} / \mathrm{iGFR}$ ratio (coefficient for non-Hispanic blacks was -0.03 [95\% CI $-0.08-0.03$ ] compared with whites, $\mathrm{p}=0.38$ )."

Under Subjects and Methods Measures of Kidney Function: it should read "Serum creatinine measurements were done in the CRIC central laboratory at University of Pennsylvania on the Hitachi Vitros 950 and then calibrated to the IDMS-traceable standardized creatinine [15], [16], [17]."

Under Results: it should read "The mean ( \pm standard deviation [SD]) $\mathrm{CrCl}$ was $52.1 \pm 25.8 \mathrm{~mL} / \mathrm{min} / 1.73 \mathrm{~m}^{2}$ and mean iGFR $48.0 \pm 19.9 \mathrm{~mL} / \mathrm{min} / 1.73 \mathrm{~m}^{2}$ (Table 1). Mean $\mathrm{CrCl} / \mathrm{iGFR}$ ratio was $1.13 \pm 0.46$ and median $\mathrm{CrCl} / \mathrm{iGFR}$ ratio was 1.09 (with interquartile range [IQR] 0.88 - 1.32)." and "The only other factors associated with the $\mathrm{CrCl} / \mathrm{iGFR}$ ratio were the use of loop diuretics (associated with higher $\mathrm{CrCl} / \mathrm{iGFR}$ ratio of $0.08, \mathrm{p}=0.001) \ldots$... and "Additionally, $\mathrm{CrCl} / \mathrm{iGFR}$ ratio in patients $(\mathrm{N}=47)$ with serum albumin $<3.0 \mathrm{~g} / \mathrm{dl}$ was $1.15 \pm 0.56$ and that in with serum albumin $\geq 3.0 \mathrm{~g} / \mathrm{dl}(\mathrm{N}=1260)$ was $1.13 \pm 0.45$ (p-value 0.89 )."

Under Discussion: it should read: "In this well characterized cohort of CKD patients with mean measured GFR of $48 \mathrm{~m} / \mathrm{min} / 1.73 \mathrm{~m}^{2}$, we found that the mean $\mathrm{CrCl} / \mathrm{GFR}$ ratio was 1.13."

Tables 1-4 should read.

\footnotetext{
* Correspondence: yclin0229@tmu.edu.tw

'Division of Nephrology, Department of Internal Medicine, Taipei Medical University Hospital, Taipei, Taiwan

2Department of Internal Medicine, School of Medicine, College of Medicine,

Taipei Medical University, Taipei, Taiwan

Full list of author information is available at the end of the article
} 


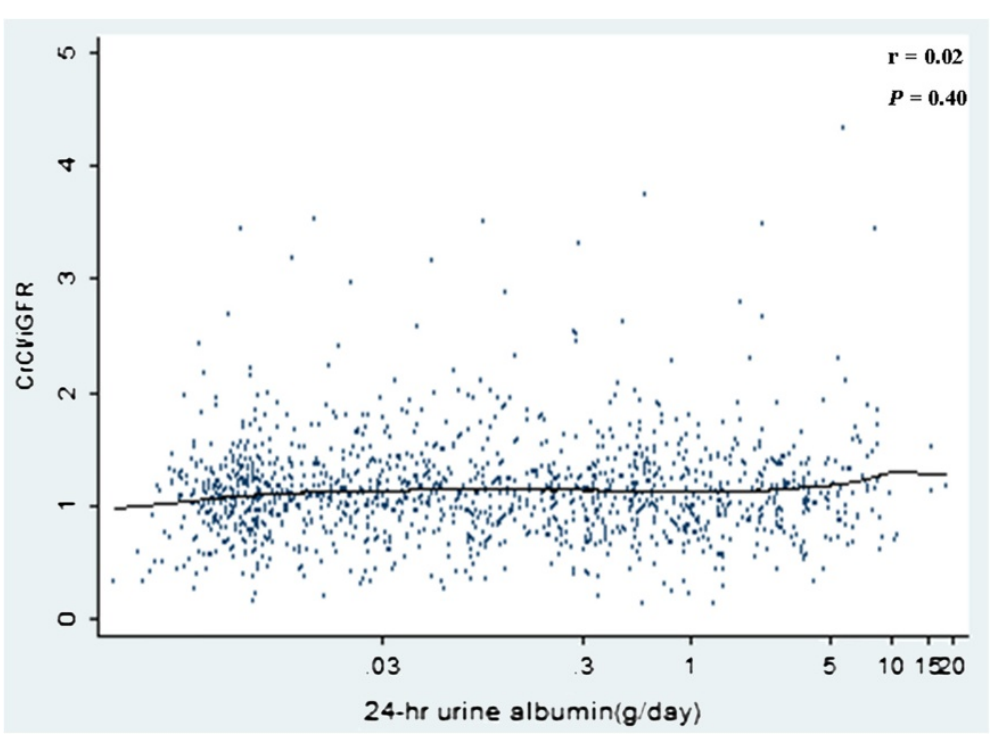

Figure 1 Scatter plot with a locally weighted scatterplot smoothing line showing that 24-hrs urinary albumin is not correlated with $\mathrm{CrCl} / \mathrm{iGFR}$ ( $\mathrm{rs}=0.02, P=0.40$ by Spearman's correlation test) (two outlier with $\mathrm{CrCl} / \mathrm{iGFR}$ ratio of $6.40,0.04$ were omitted)" And the corrected Figure has also been included.

Table 1 Characteristics of the study population $(\mathrm{N}=1342)$

\begin{tabular}{|c|c|c|c|}
\hline \multicolumn{3}{|c|}{ Creatinine clearance $(\mathrm{CrCl})\left(\mathrm{mL} / \mathrm{min} / 1.73 \mathrm{~m}^{2}\right)$} & $52.1 \pm 25.8$ \\
\hline \multicolumn{3}{|c|}{ lothalamate measured glomerular filtration rate (iGFR) $\left(\mathrm{mL} / \mathrm{min} / 1.73 \mathrm{~m}^{2}\right)$} & $48.0 \pm 19.9$ \\
\hline \multicolumn{3}{|l|}{$\mathrm{CrCl} / \mathrm{iGFR}$, mean $\pm \mathrm{SD}$} & $1.13 \pm 0.46$ \\
\hline \multicolumn{3}{|c|}{$\mathrm{CrCl} / \mathrm{iGFR}$, median $\left(25^{\text {th }}-75^{\text {th }}\right.$ percentile) } & $1.09(0.88-1.32)$ \\
\hline \multicolumn{4}{|l|}{ Laboratory results } \\
\hline \multicolumn{3}{|l|}{ Serum creatinine (mg/dL) } & $1.70 \pm 0.56$ \\
\hline Quintiles of iGFR $\left(\mathrm{ml} / \mathrm{s} / 1.73 \mathrm{~m}^{2}\right)$ & iGFR $\left(\mathrm{ml} / \mathrm{min} / 1.73 \mathrm{~m}^{2}\right)$, median (IQR) & $\mathrm{CrCl}\left(\mathrm{ml} / \mathrm{min} / 1.73 \mathrm{~m}^{2}\right)$, median (IQR) & $\mathrm{CrCl} / \mathrm{iGFR}$, median (IQR) \\
\hline $1(N=269)$ & $24.8(20.8-27.4)$ & $30.1(24.0-37.3)$ & $1.26(1.01-1.54)$ \\
\hline $2(N=268)$ & $35.7(33.0-38.5)$ & $40.3(32.0-48.8)$ & $1.14(0.89-1.40)$ \\
\hline $3(N=269)$ & $45.7(43.3-48.0)$ & $49.8(39.1-58.2)$ & $1.09(0.88-1.26)$ \\
\hline $4(N=268)$ & $56.3(53.1-59.8)$ & $58.8(47.6-69.4)$ & $1.04(0.83-1.22)$ \\
\hline $5(N=268)$ & $74.7(68.4-84.9)$ & $77.8(61.8-91.8)$ & $1.00(0.82-1.16)$ \\
\hline
\end{tabular}

Table 3 The association of 24-hrs urinary albumin in categorical classifications and $\mathrm{CrCl} / \mathrm{iGFR}$ ratio in the regression model $(\mathrm{N}=1342)$

\begin{tabular}{|c|c|c|c|c|}
\hline & $\begin{array}{l}\text { Normal (24-hrs urine } \\
\text { albumin }<30 \mathrm{mg} \\
\mathrm{N}=515)\end{array}$ & $\begin{array}{l}\text { Microalbuminuria (24-hrs urine } \\
\text { albumin } 30 \text { to } \leqq 299 \mathrm{mg} ; \mathrm{N}=343 \text { ) }\end{array}$ & $\begin{array}{c}\text { Macroalbuminuria } \\
(24-\mathrm{hrs} \text { urine albumin } \\
300 \text { to } \leqq 2999 \mathrm{mg} ; \mathrm{N}=378)\end{array}$ & $\begin{array}{l}\text { Nephrotic-range proteinuria } \\
\text { (24-hrs urine albumin } \\
\geqq 3000 \mathrm{mg} ; \mathrm{N}=106 \text { ) }\end{array}$ \\
\hline \multicolumn{5}{|l|}{$\begin{array}{l}\text { Absolute change in } \\
\mathrm{CrCl} / \mathrm{iGFR}(95 \% \mathrm{Cl})\end{array}$} \\
\hline Unadjusted & reference & $0.05(-0.01-0.11) P=0.12$ & $0.02(-0.04-0.08) P=0.48$ & $0.06(-0.03-0.16) P=0.20$ \\
\hline Multivariate adjusted $^{\mathrm{a}}$ & reference & $0.06(-0.01-0.12) P=0.08$ & $0.04(-0.02-0.11) P=0.21$ & $0.10(-0.01-0.21) P=0.07$ \\
\hline
\end{tabular}

$\mathrm{CrCl}=$ Creatinine clearance; IGFR $=\mathrm{I}^{125}$ lothalamate measured glomerular filtration rate.

${ }^{a}$ Adjusted for age, sex, race/ethnicity, use of loop diuretics, hemoglobin A1C levels. 
Table 4 The association of race/ethnicity categories and $\mathrm{CrCl} / \mathrm{iGFR}$ in the multivariate regression $\mathrm{model}(\mathrm{N}=1342)$

\begin{tabular}{lcccc}
\hline & $\begin{array}{c}\text { Non-Hispanic } \\
\text { white }(\mathbf{N}=\mathbf{5 6 8})\end{array}$ & $\begin{array}{l}\text { Non-Hispanic } \\
\text { black }(\mathbf{N}=\mathbf{4 9 4})\end{array}$ & Hispanics $(\mathbf{N}=\mathbf{1 8 8})$ & Others $(\mathbf{N}=\mathbf{9 2})$ \\
\hline $\begin{array}{l}\text { Absolute change in CrCl/iGFR ratio }(95 \% \mathrm{Cl}) \\
\text { Unadjusted }\end{array}$ & reference & $-0.03(-0.08-0.03) P=0.34$ & $0.01(-0.07-0.08) P=0.89$ & $-0.01(-0.12-0.09) P=0.79$ \\
Multivariate adjusted $^{\mathrm{a}}$ & reference & $-0.03(-0.08-0.03) P=0.38$ & $0.01(-0.06-0.09) P=0.72$ & $0.01(-0.10-0.11) P=0.91$ \\
\hline
\end{tabular}

$\mathrm{CrCl}=$ Creatinine clearance; iGFR $=\mathrm{I}^{125}$ lothalamate measured glomerular filtration rate.

Others = American Indian/Alaskan Native, Asian/Asian American, or Native Hawaiian/Other Pacific islander.

${ }^{a}$ Adjusted for age, sex, use of loop diuretics, hemoglobin A1C.

\section{Author details}

'Division of Nephrology, Department of Internal Medicine, Taipei Medical University Hospital, Taipei, Taiwan. ${ }^{2}$ Department of Internal Medicine, School of Medicine, College of Medicine, Taipei Medical University, Taipei, Taiwan. ${ }^{3}$ Division of Nephrology, School of Medicine, University of California-San Francisco, San Francisco, CA, USA. ${ }^{4}$ Department of Epidemiology and Biostatistics, School of Medicine, University of California-San Francisco, San Francisco, CA, USA. ${ }^{5}$ Division of Research, Kaiser Permanente Northern California, Oakland, CA, USA.

Received: 29 May 2014 Accepted: 29 May 2014

Published: 6 June 2014

\section{Reference}

1. Lin YC, Bansal N, Vittinghoff E, Go AS, Hsu CY: Determinants of the creatinine clearance to glomerular filtration rate ratio in patients with chronic kidney disease: a cross-sectional study. BMC Nephrology 2013, 14:268.

doi:10.1186/1471-2369-15-85

Cite this article as: Lin et al:: Correction: Determinants of the creatinine clearance to glomerular filtration rate ratio in patients with chronic kidney disease: a cross-sectional study. BMC Nephrology 2014 15:85.

\section{Submit your next manuscript to BioMed Central and take full advantage of:}

- Convenient online submission

- Thorough peer review

- No space constraints or color figure charges

- Immediate publication on acceptance

- Inclusion in PubMed, CAS, Scopus and Google Scholar

- Research which is freely available for redistribution 